\title{
Rocks Fall in the Cape Aokas (Bsjaia): Geological Study Contribution and Reinforcement of the Rocky Slope
}

\author{
Hallal Nassim ${ }^{1 *}$, Bougdal Rachid ${ }^{2}$ and Laurent Dubois ${ }^{3}$ \\ ${ }^{1}$ Centre de Recherche en Astronomie, Astrophysique et Géophysique (CRAAG), Algeria. \\ ${ }^{2}$ Faculté des sciences de la terre, de géographie et de l'aménagement du territoire (FSTRGAT/ USTHB), Algaria \\ ${ }^{3}$ Centre d'étude et d'expertise sur les risques, l'environnement, la mobilité et l'aménagement, France
}

Submission: June 16, 2018; Published: August 07, 2018

*Corresponding author: Hallal Nassim, Centre de Recherche en Astronomie, Astrophysique et Géophysique (CRAAG), Algeria,

Email: nhallal@usthb.dz

\begin{abstract}
The Cape Aokas situated in the oriental coastal region of Béjaïa city (Algeria). The cape takes its origin from the babor mountain chain to the Mediterranean Sea along the Aokas city. Its relief is characterized by abrupt slopes. On May 9th, 2005 rocks fall in large mass $(20,000$ to $30,000 \mathrm{~m} 3$ ) from one of the walls constituting the cape, blocked traffic on a busy road (RN ${ }^{\circ}$ ) a the entrance of Aokas city. The excavation work of fallen rocks was quickly undertaken by the authorities: 23 days after the rock fall, the road was reopened to traffic. The topometric monitoring was be implemented between April and September 2014 during the summer. The reflection was started to find the best way to strength permanently the rocky slope. In this paper, we present a comparison between the stabilizing system applied to the rocky slope and an optimization proposal in both following cases: without earthquake and under reference earthquake solicitation.
\end{abstract}

Keywords: Aokas cape; Rock fall; Topometric monitoring; Passive nailing;

\section{Introduction}

A spectacular cliff rock fall occurred on May 9th, 2005 covered the roadway of National Road $\mathrm{N}^{\circ} 9$ on a about $150 \mathrm{~m}$ linear (Figure 1), at the entrance to the Aokas town (Figure 2). These rocks fall, preceded by several rocks, have not made a victim. The traffic on this busy road, the only way of communication between neighboring districts: Jijel and Béjaïa (about 20,000 vehicles/ day) was completely blocked for three weeks, isolating the Aokas city. The old national road, located $60 \mathrm{~m}$ beneath the modern one, was completely destroyed and constraining residents to a long detour to join Béjaïa. An important water pipe was also damaged leading to severe restrictions for the population. The rocks fall, which mobilized some 20,000 to $30,000 \mathrm{~m} 3$ of rock materials was alienated from a fractured limestone cliff at the entrance to a small tunnel that overlooks the city of Aokas (Figure 1). The fallen rocks are fragmented into blocks of any size, with more than $100 \mathrm{~m} 3$. This paper describes the geological and structural setting of the site and the safety work made (topometric monitoring, passive nailing of the new rock slope).

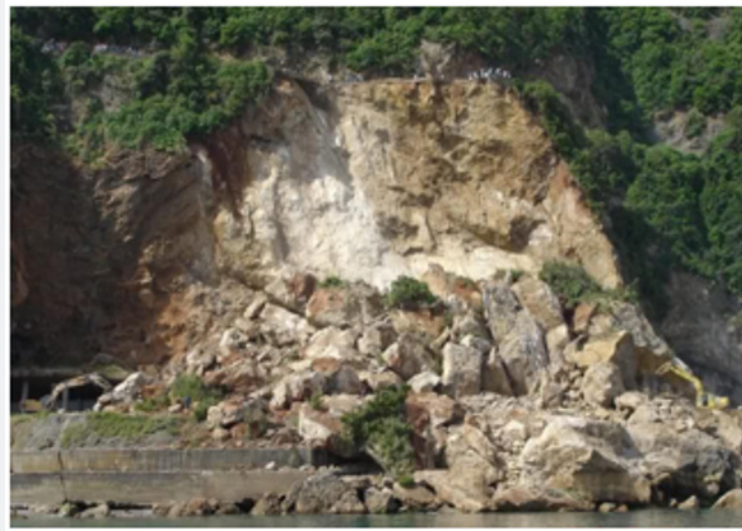

Figure 1: Global view of the cliff rock fall on the NR 9 at the western entrance of Aokas. 


\section{Civil Engineering Research Journal}

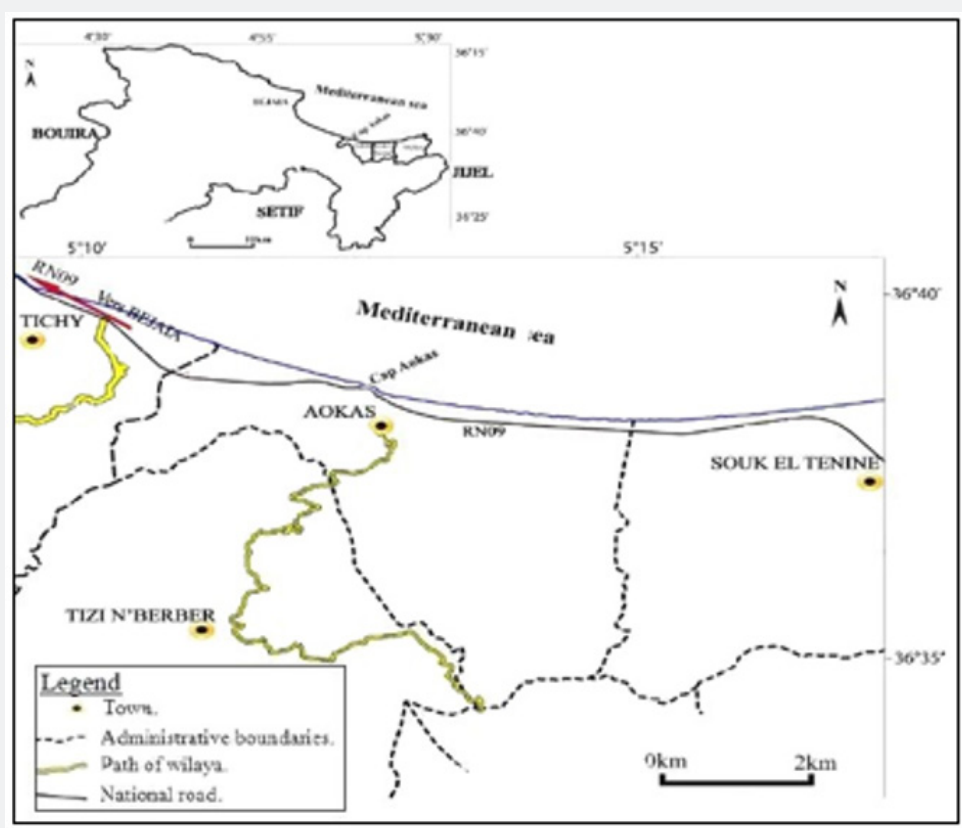

Figure 2: Location map of the Cap Aokas rock fall.

\section{Geology}

Aokas city is bordered in the west by a limestone massif of the Lower Jurassic [1]. These hard limestones, of dark grey color and brown patina form the skeleton of the Mount Imma Tadrart (Figure 3). Most of the outcrops show intense deformations which expressed themselves by fractures more at least closed and papered with calcite and with deposits of iron oxides. A feature of Calcareous breach fairly homogeneous and finely cemented intercalates into this massive limestone. They probably correspond to a weakness area [2]. Locally, coarse colluviums cover the steep slopes of this relief. Along the spur rocky which dominates the sea, and sometimes in alternation with colluvions, we find veneers of gravelly terraces marine origin (Figure 4). The height difference between the roof of these former terraces (Quaternary), and the level of current sea (Figure 4) testify, not of the eustatisme phenomenon, but the shore uplift by recent and very active tectonic movements. For example, the superficial earthquake of Boumerdès engendered a spectacular coast uprising, about $50 \mathrm{~km}$ linear, esteemed to $75 \mathrm{~cm}$ near the epicenter, then decreasing gradually to become null in Cape Djinet, approximately $35 \mathrm{~km}$ on the West of Tigzirt [3].

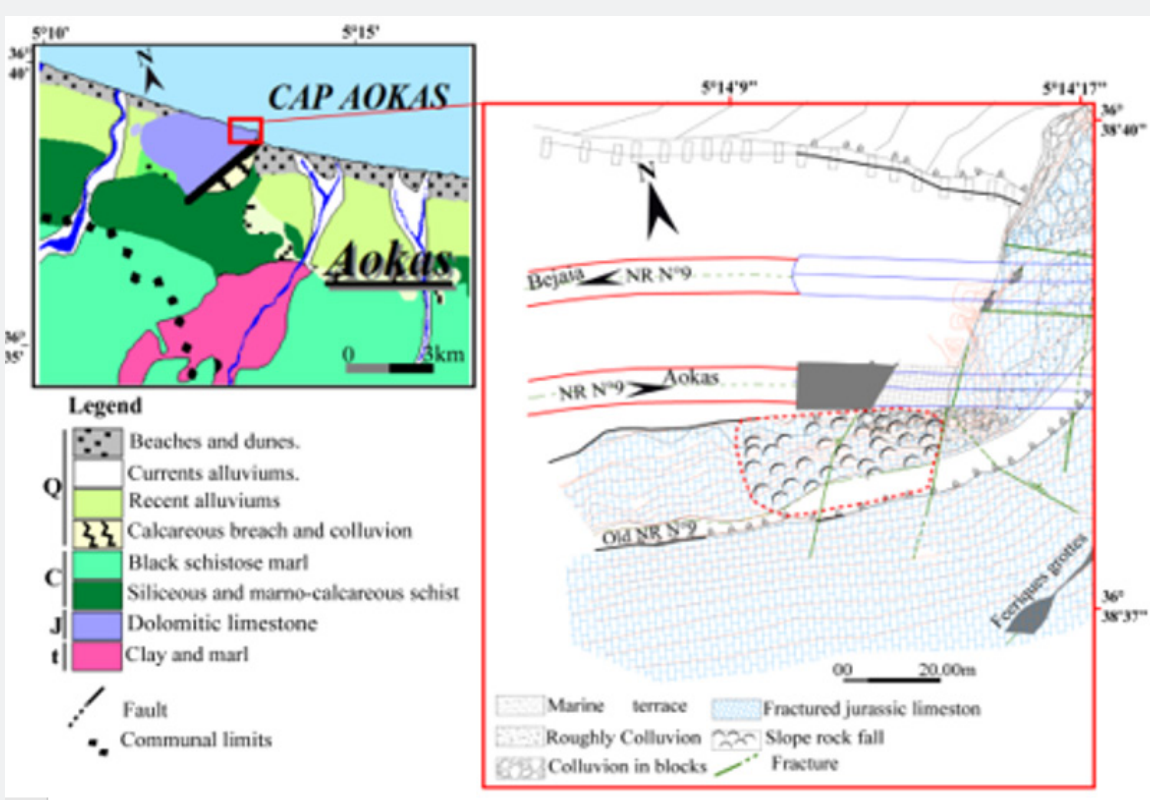

Figure 3: Geologic map and schematic plan of the study area. 


\section{Civil Engineering Research Journal}

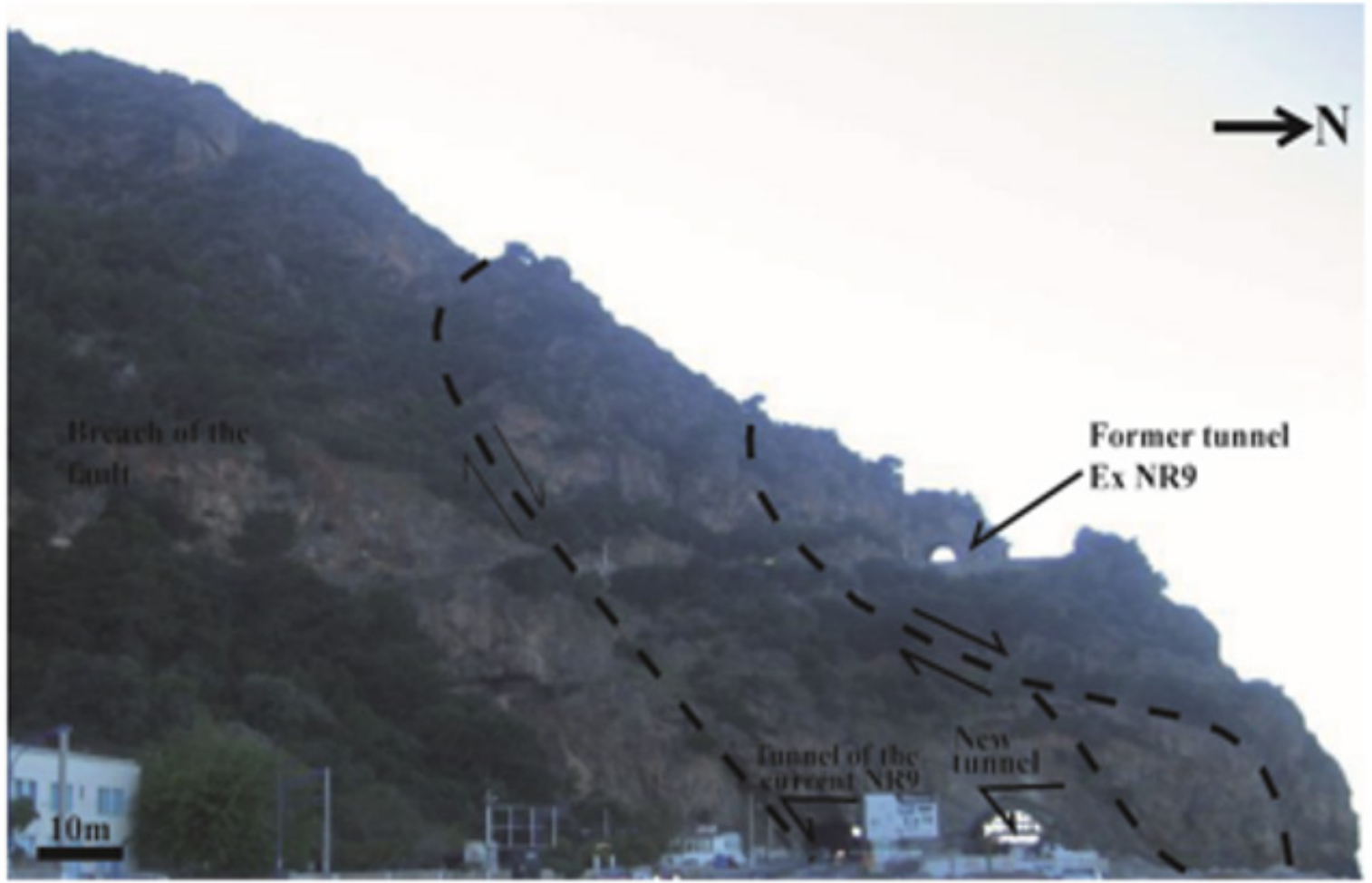

Figure 4: Cutting of the rock massif by normal faults connected to the first family.

\section{Tectonic}

The calcaro-dolomitic massif of Cape Aokas is affected by a strong deformation due to the Miocene alpine paroxysmal phase [4]. It is crossed by a big vertical fault N010 ${ }^{\circ} \mathrm{E}$ (Figure 3). The fault extension towards the south bounds the massif calcareous and controls its morphology. It is characterized by a thick zone of breaches. Two families of faults were identified. The first one presents a direction $\mathrm{N} 015^{\circ} \mathrm{E}$ to $\mathrm{N} 045^{\circ} \mathrm{E}$; it is about faults having replayed into normal faults (Figure 5), at the origin of break mechanisms in the versant of sliding plan type to the northwest [5]. The second family presents a direction $\mathrm{N} 080^{\circ} \mathrm{E}$ to $\mathrm{N} 100^{\circ} \mathrm{E}$ quasi-parallel to the cliff forehead. a

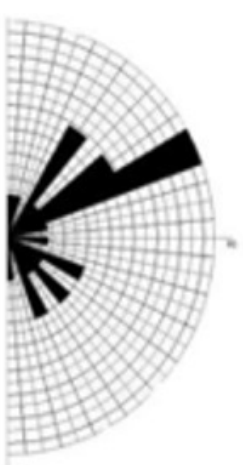

b

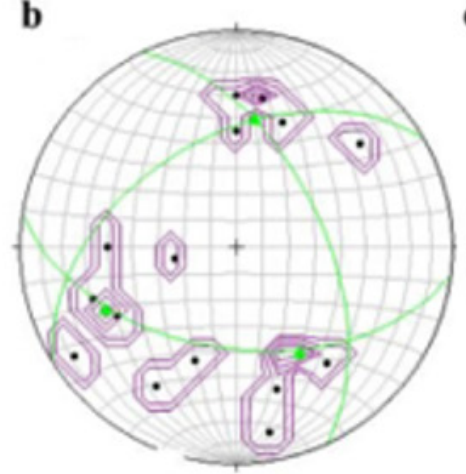

c

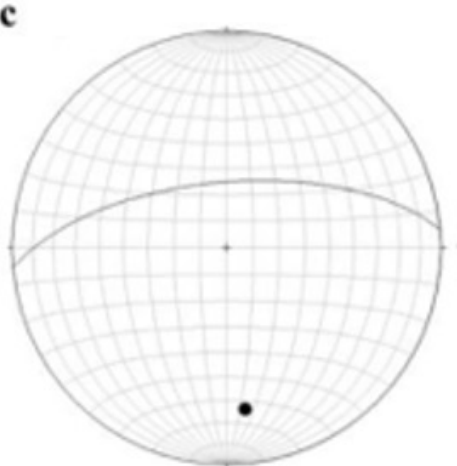

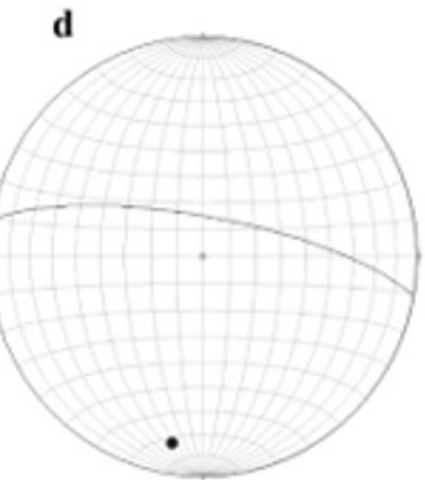

Figure 5: a) Rosette of the fractures frequency in surface. b) Stereographic projection of the in-surface fractures. (Canvas of Schmidt, lower hemisphere) [5]. c) Cyclographic trace and pole of rocky sliding plan. (Canvas of Schmidt, lower hemisphere). d) Cyclographic trace and potential plan pole before sliding. (Canvas of Schmidt, lower hemisphere).

The Figure 6 shows the fracture caused by the tectonic constraints undergone by the rock during its geologic history. They present, generally, the same orientation as the fractures families observed in the Cape Aokas tunnel [2,5,6]. These analyses confirm the existence of three main directions, the first one oriented $\mathrm{N} 015^{\circ} \mathrm{E}$ to $\mathrm{N} 055^{\circ} \mathrm{E}$ with a dip of $40^{\circ}$ to $86^{\circ}$ to the northwest and the second is oriented N085 ${ }^{\circ} \mathrm{E}$ to $\mathrm{N} 100$ ${ }^{\circ} \mathrm{E}$ with a dip of $60^{\circ}$ to $75^{\circ}$ northward. The most important 


\section{Civil Engineering Research Journal}

fractures are replayed to the faults collapses. The third fracture family is oriented $\mathrm{N} 120^{\circ} \mathrm{E}$ to $\mathrm{N} 155^{\circ} \mathrm{E}$ with a dip of $44^{\circ}$ to $50^{\circ}$ to the northeast. The opening spaces and discontinuities are very variable; they contain calcite crystallized and iron oxide deposits [5].

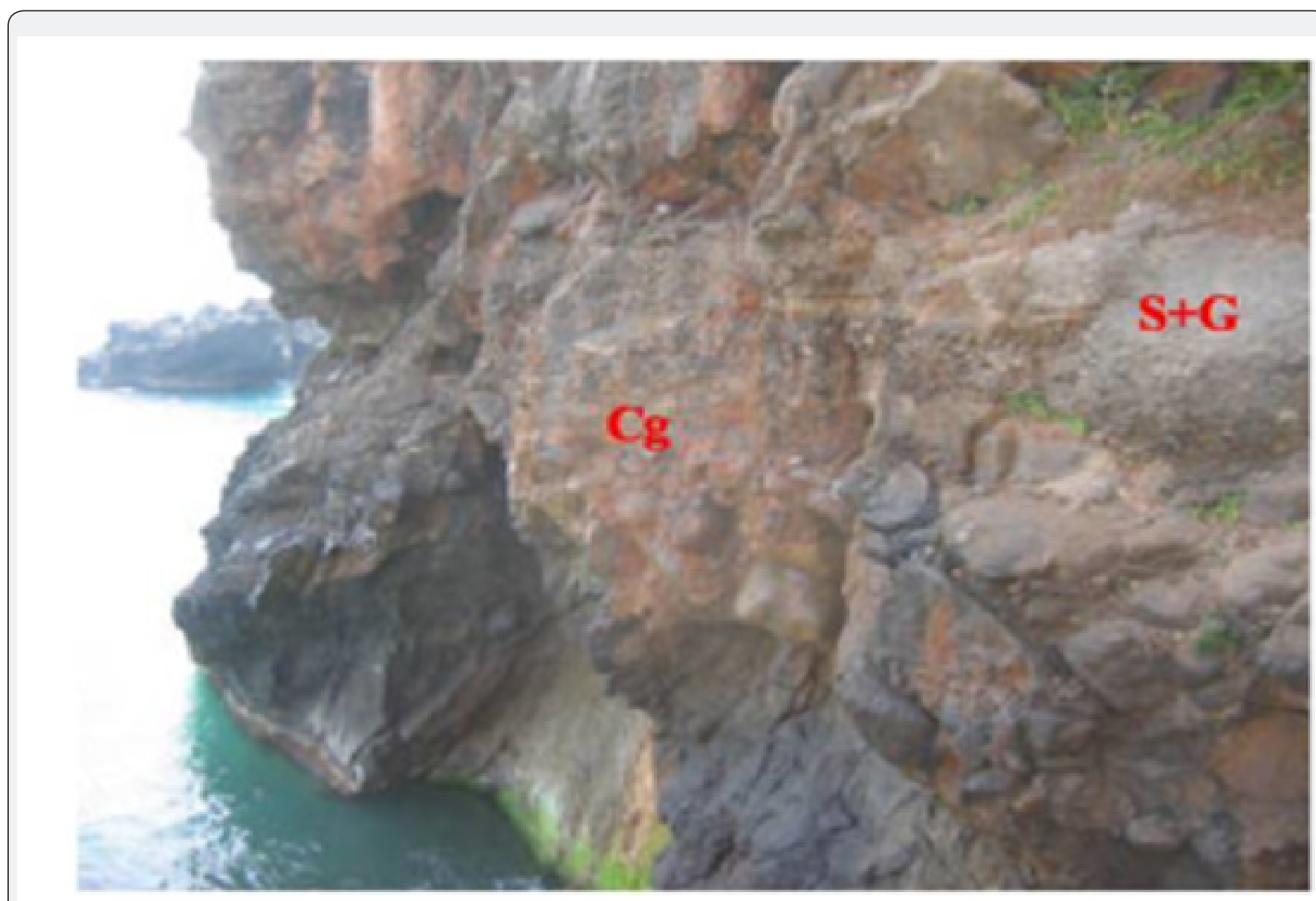

Figure 6: Conglomerates $(\mathrm{Cg})$, sands and gravels $(S+G)$, quaternary, marine, near the shore.

\section{Seismicity of the Aokas Region}

Béjaïa province has recorded during these last year's relatively numbers of high magnitude earthquakes:

a. In March 2006, an earthquake of energy magnitude of 5,0Mw (USGS) has affected the Laâlam region at Kherrata [7], approximately $15 \mathrm{~km}$ in the southeast of the study area. The earthquake caused the reactivation of the former sliding and the falls of blocks since limestone cliffs at Melbou [8].

b. In November 2012, an earthquake of magnitude Mw of 5,1 (CRAAG) which the epicenter was situated $9 \mathrm{~km}$ in northeast of Béjaiia city and in $10 \mathrm{~km}$ of the study area.

c. In May 2013, an earthquake of a magnitude $M w=5,5$ (CRAAG) which the epicenter was situated to $6 \mathrm{~km}$ east of the study area.

In Aokas area, an earthquake of magnitude (Mw) superior to 5 can thus reactivate or activate diverse ground movements by disturbance of the initial equilibrium conditions. So, a versant with abrupt slope, stable under static conditions can be in imbalance under dynamic solicitation. The best examples are the rock fall and the landslides of Beni Ourtilane in $2000(\mathrm{Mw}=5,6)$ and Laâlam in $2006(\mathrm{Mw}=5,0)$ [9]. The seismic activity in Aokas area and the ground movement risks have obliged the authorities to look for a solution to stabilize the rocky slope cleared by the rock fall of May 2005 and to set up a device of measures allowing evaluating the slope deformations, in the wait to the realization of the reassurance works.

\section{Karstification}

A Jurassic limestone particularity of Aokas Cape is the presence of natural dissolution cavities. The fairy cave, where the entrance is situated in the tunnel (Figure 7), nearby the place where the rocks have fallen, witnessing the strong aptitude of this training to the karstification. 


\section{Civil Engineering Research Journal}

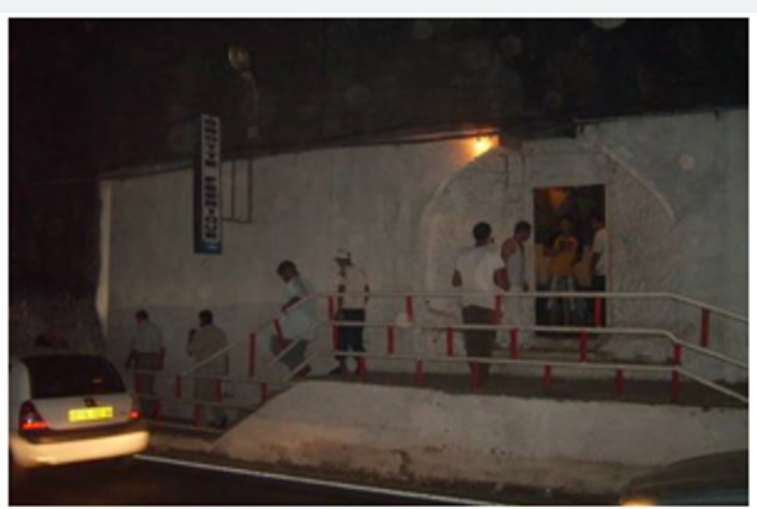

Figure 7: Entrance of the fairy cave.

\section{Description of the Rock Fall}

At the west entrance of the Aokas city, the tunnel head is extended by a protection system with the armed concrete, to straight of the conglomeratic slope, susceptible to generate falls of small blocks. The rock fall occurred simultaneously (or with training effect) at the level of two distinct geological formations from the upstream slope of the NR 9:

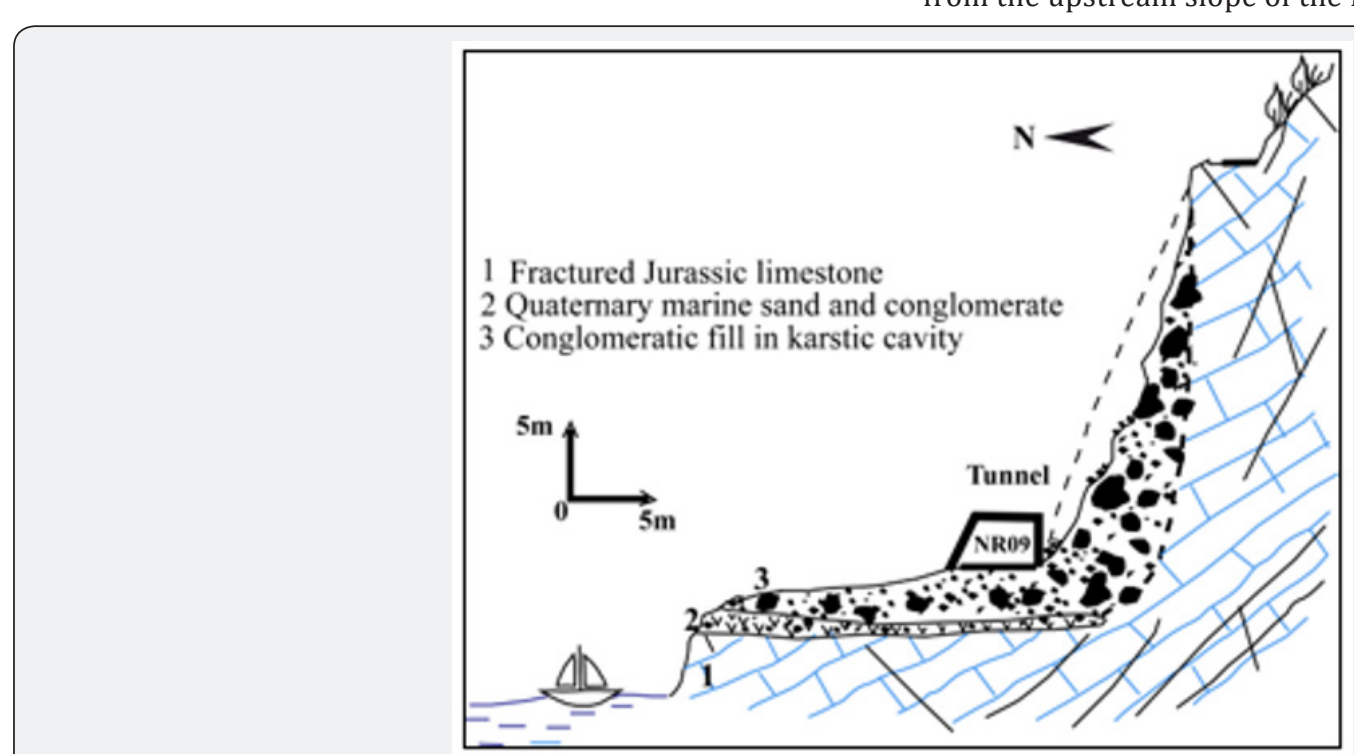

Figure 8: Rock fall in the conglomeratic slope.

I. At the level of the calcareous slope (Figures 8 \& 9), after removing the collapsed rocks, a net discontinuity in the surface was discovered, corresponding to one of the main rock fracturing plans. This plan (s) (Figure 8), of direction $\mathrm{N} 080^{\circ} \mathrm{E}$ to $\mathrm{N} 100^{\circ} \mathrm{E}$ quasi-parallel to the NR 9, present a dip downstream of $60^{\circ}$ to $75^{\circ}$, completely unfavorable to the rocky slope stability. According to the statistical analysis of the fractures measures and the geologic cup realized along the collapsed slope, a new rock fall of big mass occurring is possible according to the plan F1 (Figure 8) with same mechanism of "sliding plan".

II. The conglomeratic slope (Figure $9 \& 10$ ), situated at the tunnel entrance, presents a relatively low resistance because of a partial cementation and alteration in the surface. His stability state limit is improved by the structure construction of concrete protection armed extending the tunnel. This structure largely destroyed by the calcareous blocks of the rock fall in May 2005. It was intended to protect the road users and resist to the falls impacts of small blocks. The attentive observation of the conglomeratic slope cleared by the rock fall, in the tunnel entrance, shows that it is about a material of karstic cavity filling (Figures 9 \& 10). This cavity, of downward flared shape, is extended upward, as high as the former NR 9, by an open and shrunk section, and allowed the accumulation of masses fallen rocks. The presence of marine pudding (pebbles and sands with fossils fragments) which appears near the shore (Figures $4 \& 10$ ) and which extended to the karstic cavity basis; show that the latter was opened towards the sea, before its filling. The realized horizontal poll data in the cavity conglomerates show that the latter is of low extension. The visit of the "magic caves" accessible from the former tunnel and approximate location 


\section{Civil Engineering Research Journal}

of the big room shows that this one is separated from the collapsed cavity by a thick rocky panel of $20 \mathrm{~m}$ to $30 \mathrm{~m}$. The conglomeratic slope stability after rock fall remains precarious. The important problem at the Short-term is the frequent falls of small blocks, and not a new rock fall.

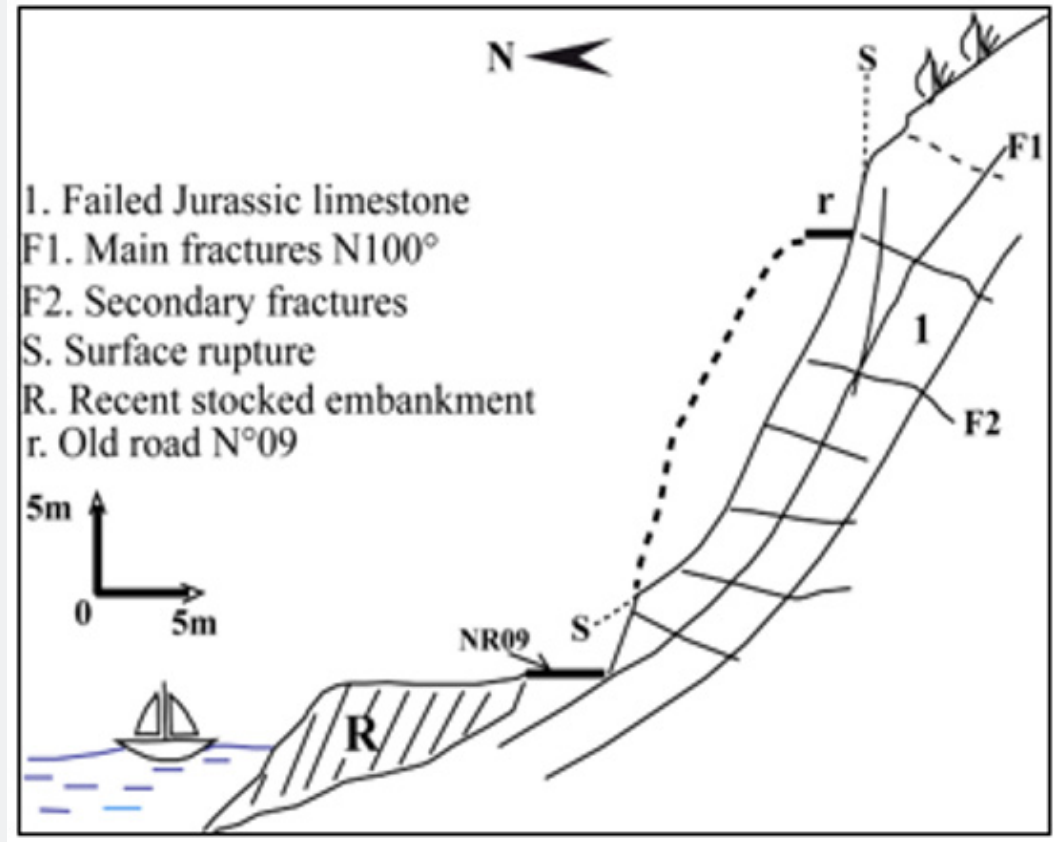

Figure 9: Rock fall plan of the calcareous slope.

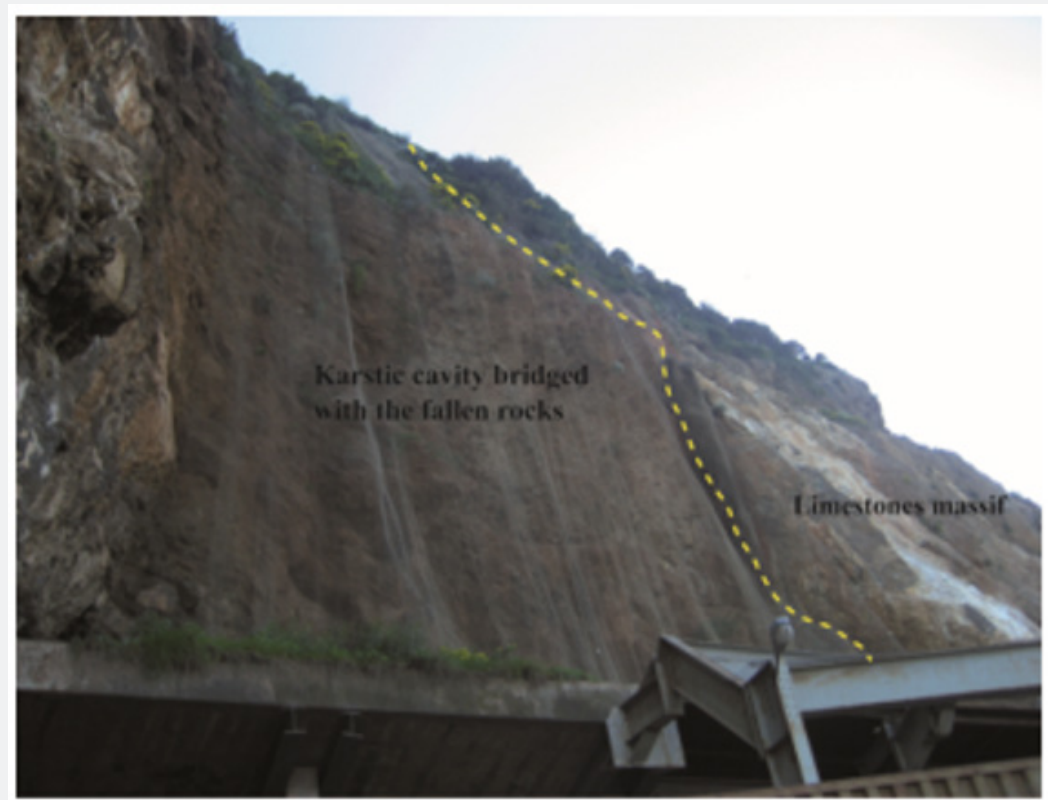

Figure 10: Breaking surface (S) cleared by the rock fall in the calcareous slope and destabilization of the fallen rocks of karstic cavity.

On April 2014, a rock fall of about $100 \mathrm{~m} 3$ is occurred in the Cape Aokas calcareous massif at the level of the former career front (Figure 11), upstream the former NR 9 and in 1, $1 \mathrm{~km}$ to the rock fall area of May 2005. The plan cleared by this rock fall corresponds to stratification plan (PS), of direction included between $\mathrm{N} 050^{\circ} \mathrm{E}$ and $\mathrm{N} 060^{\circ} \mathrm{E}$ with a downstream dip of $70^{\circ}$. Recently, in February 2015, seven persons were killed, and 20 others injured by a rocks fall near the Cape Aokas tunnel $(500 \mathrm{~m}$ of the head West, Tala Khaled) in Pk 26 of the NR 9 at the East of Béjaïa (Figure 12). 


\section{Civil Engineering Research Journal}

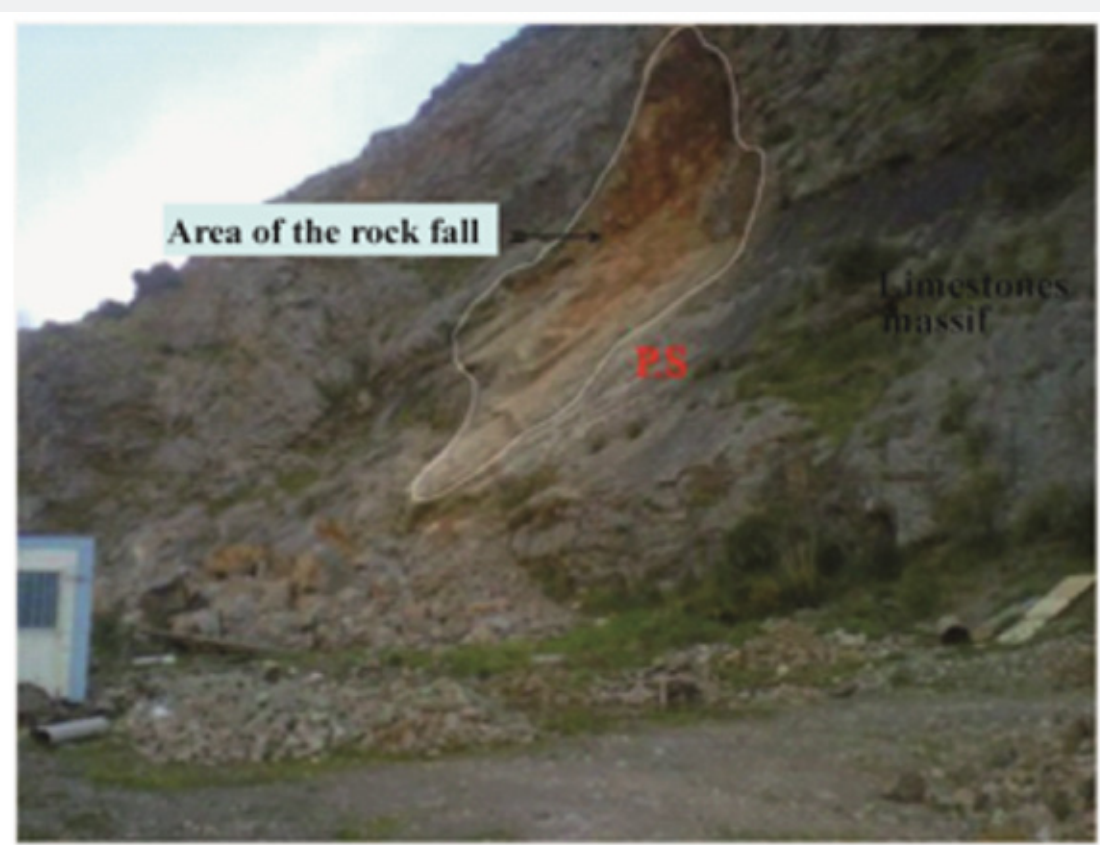

Figure 11: Rock falls at the former career front in Aokas area.

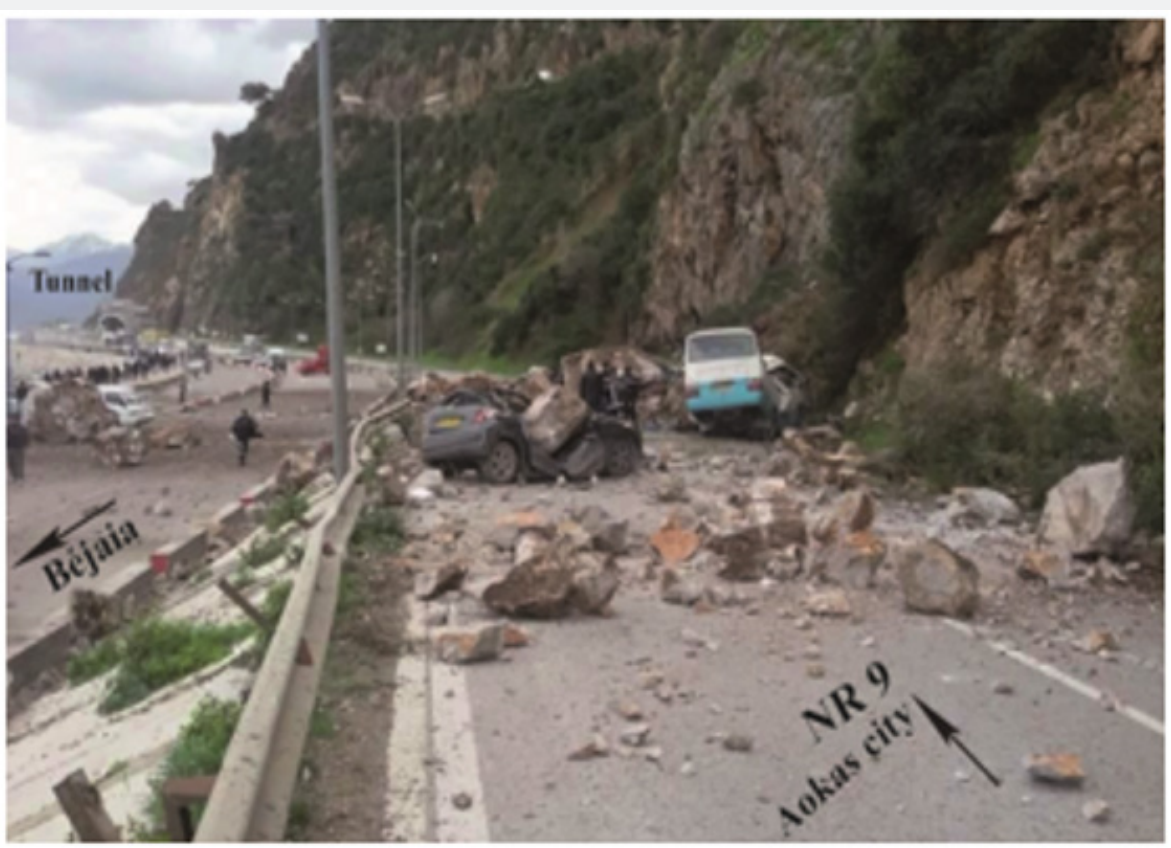

Figure 12: Damages caused by the rocks fall of February, 2015.

The rocks fall is occurred in outside period of frost after an episode of moderated precipitation between February 14th and February 21st, 2015 (36mm to Béjaïa, Station of BéjaïaAirport). Since the beginning of 2015, the North of Algeria knew a moderate seismic activity, Especially the Western and the Southern of Algiers. No earthquake of magnitude superior then 3 was registered in the region of Béjaïa.

This spectacular rock fall mobilized about $50 \mathrm{~m} 3$ to $100 \mathrm{~m} 3$ rocky materials. According to witnesses, the first phase of rocks fall corresponded to the detachment of two dihedral unitarian volume esteemed between 3 and $5 \mathrm{~m} 3$ from a rocky bar, at a height of $160 \mathrm{~m}$ of the current road (Figure 13). These two dihedrals have provoked the fall and the other blocks detachment of different volumes in the versant unstable equilibrium. The observations and the made measures show that both collapsed compartments were bounded by three plans. The first two correspond to both fractures families (F1 and F3) and the third plan corresponds to the stratification plan, a direction between $\mathrm{N} 050^{\circ} \mathrm{E}$ and $\mathrm{N} 060^{\circ} \mathrm{E}$ with an unfavorable downstream dip of $70^{\circ}$. 


\section{Civil Engineering Research Journal}

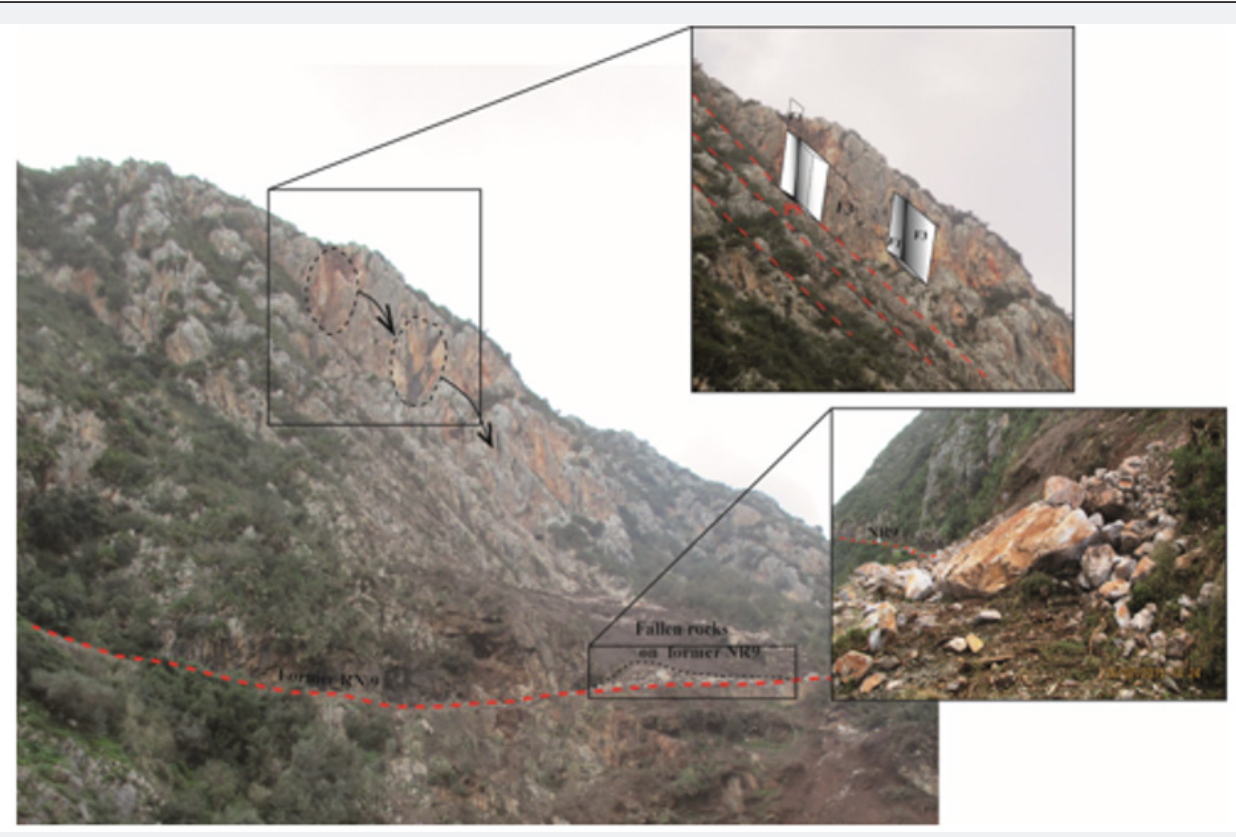

Figure 13: Panoramic photos of dihedrals detached and fallen rocks in the former NR9.

\section{Topometric Mnitoring of the Rock Fall Scar}

Since May 2005, the both calcareous and conglomerate slopes did not present a noteworthy instability. After the rock fall of April 2014 in the same massif, six topographic marks for the realization of infrared geodesic measures were set up on the potentially unstable compartments at the level of the rock fall scar of May 2005. The measures results of the totals displacements between April and September 2014 in six marks are represented on the graphs of the Figure 14 below.
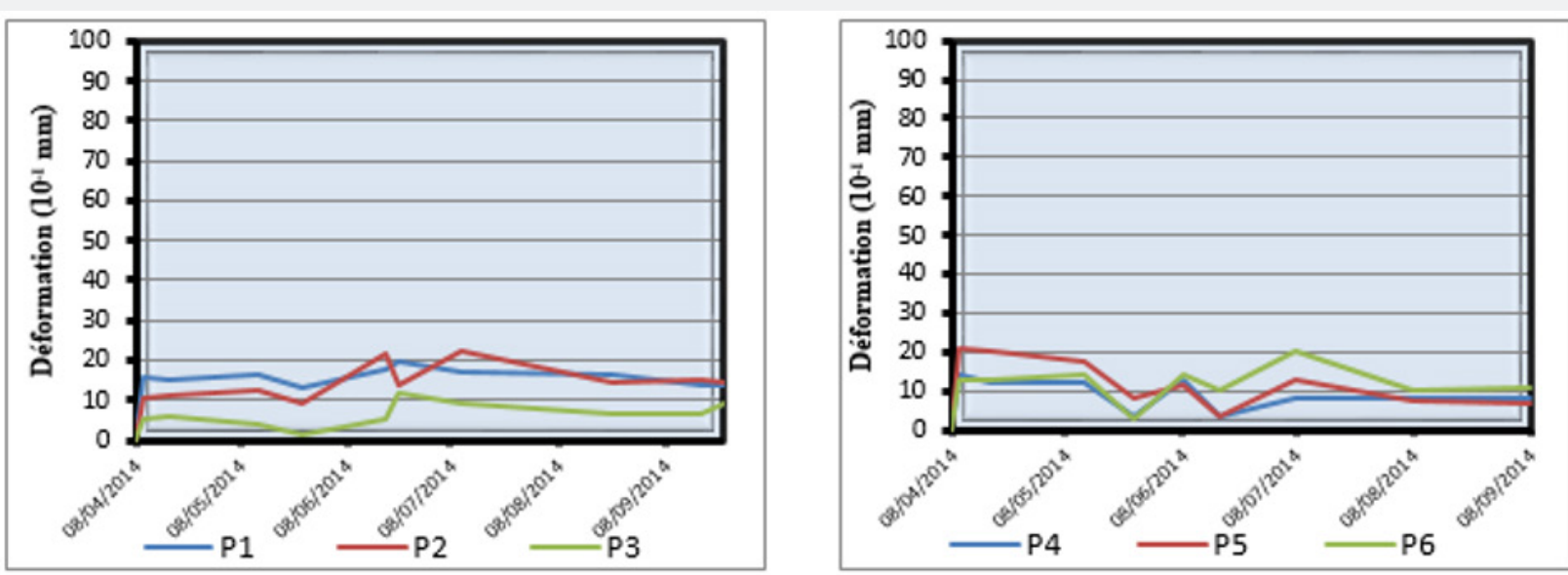

Figure 14: Total results of the measures displacements.

From totals results of displacements made during a period of six months, we notice that:

i. Until June 2014, the measures displacements remained lower than $2 \mathrm{~mm}$.

ii. During the summer period, characterized by an important tourist activity and very dense road traffic on the NR9, the displacements measures varied between $0,5 \mathrm{~mm}$ and $2,3 \mathrm{~mm}$.

iii. Since the beginning of august, 2014, no deformation was recorded.

The total displacements measured remained lower than 2 , $5 \mathrm{~mm}$, thus lower to the uncertainty of measure.

During the same period, some compartments localized in the downstream slope, the visual observations highlighted an opening of fractures. This movement of the millimeter-length order (lower than $10 \mathrm{~mm}$ ) occurred at the level of two fractures plans oriented $\mathrm{N} 080{ }^{\circ} \mathrm{E}$ to $\mathrm{N} 090{ }^{\circ} \mathrm{E}$ with a downstream dip of $65^{\circ}$. 


\section{Civil Engineering Research Journal}

\section{Geotechnical Characteristics}

Table 1: Geomechanical characteristic of limestone massif in Cape Aokas.

\begin{tabular}{|c|c|c|c|c|c|c|c|c|c|c|}
\hline & $\gamma \mathbf{h}$ & wn & $\mathrm{Sr}$ & Rc & Is50 & E & Rtb & \multicolumn{3}{|c|}{ RQD } \\
\hline & $\mathrm{kN} / \mathrm{m} 3$ & \multicolumn{2}{|c|}{$\%$} & \multicolumn{4}{|c|}{ (MPa) } & 0 to $3 \mathrm{~m}$ & 3 to $5 \mathrm{~m}$ & 5 to $9.6 \mathrm{~m}$ \\
\hline $\begin{array}{c}\text { Testing } \\
\text { Number }\end{array}$ & 5 & 5 & 5 & 5 & 12 & 15 & 4 & \multicolumn{3}{|c|}{$\%$} \\
\hline Average & 25 & 0,2 & 0,3 & 18 & 1,9 & 2600 & 2,9 & 21 & 43 & 78 \\
\hline
\end{tabular}

$\mathrm{V}_{\mathrm{h}}$ : Volume weight (Natural water content).

$\mathrm{w}_{\mathrm{n}}$ : Natural water content.

Sr: Degree of saturation.

Rc: Simple compression resistance.

Is50: Compression resistance index between points for a distance inter-points equals in $50 \mathrm{~mm}$ (Franklin test).

E: Module of Young.

Rtb: Indirect traction resistance (Brazilian test).

RQD: Rock Quality Designation.

The laboratory testing results realized during the doubling works of Cape Aokas tunnel on samples taken in a horizontal poll realized near the rocks fall of May 2005 are summarized in the following Table 1:

We notice that:

a. The compression resistance values are relatively lower with regard to Franklin index with a report Rc/Is50 of the order of 9 while this report is usually between 20 to 30 .

b. The Young module values are relatively low compared with compression resistance values with a report E / Rc of the 142 order while this report is usually of about $250-750$ order for this rock type.

c. The average RQD values vary from $21 \%$ to $78 \%$, with a bad massif quality until $5 \mathrm{~m}$ of depth and good one beyond $5 \mathrm{~m}$ of depth.

In synthesis, the matrix is weakly resistant and is averagely stiff. It is characterized of a porous limestone (presenting an order of $10 \%$ total porosity). It is indeed possible that in the proximity of the major vertical fault of direction N010 ${ }^{\circ} \mathrm{E}$ met at the oriental border level of the rocks fall, limestone is transformed to dolomite during an intense activity period (Dolomitisation of replacement and recrystallising having been able to destroy the limestone original texture), then by time (at the origin of dissolution phenomena in the mass and thus micropores).

\section{Strengthening of the Rocky Slope}

The nailing solution of the rocky slope by passive anchoring was retained with a sizing to the limit balance for the following hypotheses:
I. The absence of cohesion and water pressure along the potential sliding plan,

II. The seismic zoning established by the Earthquakeresistant Genius Center (CGS, on 1999) modified and completed further to Boumerdès earthquake in 2003, class the Aokas region in average seismicity area (area II a). For the justification in pseudo-statics of an important vital structure from the view safety point, the horizontal acceleration coefficient of the reference earthquake to be taken into account is equal in: $\sigma \mathrm{H}=0,25$. The vertical acceleration coefficient $\sigma \mathrm{V}$ is equal to the third of the coefficient $\sigma \mathrm{H}$,

III. The anchoring steel working rate is limited in the middle of the elastic limit under static solicitation (except earthquake) and to the elastic limit under seismic solicitation,

IV. The sealing length beyond the potential sliding plan is the maximal value between the value deducted from traction test on nail (allowing reaching the unitarian side friction noted qs) and a fixed value equals 70 times the diameter of the anchoring steel bars.

Consider the hypotheses exposed above and those exposed on the schematic (Figure 15) and in the Table 2 below, the rocky slope safety factor towards the sliding plan, noted Cs, can be calculated in the equilibrium limit according to the following relations:

a) Slope not strengthened except seismic solicitation:

$$
C_{S}=\frac{\tan \varphi_{a}}{\tan \beta}
$$

b) Slope not strengthened under seismic solicitation (with vertical component oriented upward): 


\section{Civil Engineering Research Journal}

$$
\mathrm{C}_{\mathrm{S}}=\frac{\left[\left(1-\sigma_{\mathrm{v}}\right) \cos \beta-\sigma \sin \beta\right] \tan \varphi_{\mathrm{a}}}{\left(1-\sigma_{\mathrm{v}}\right) \sin \beta-\sigma_{\mathrm{H}} \cos \beta}
$$

c) Slope strengthened except seismic solicitation:

$$
\mathrm{C}_{\mathrm{S}}=\frac{\tan \varphi_{\mathrm{a}}+\mathrm{R}_{\mathrm{A}} / \mathrm{W}}{\tan \beta}
$$

d) Slope strengthened under seismic solicitation (with vertical component oriented upward):

$$
\mathrm{C}_{\mathrm{S}}=\frac{\left[\left(1-\sigma_{\mathrm{v}}\right) \cos \beta-\sigma_{\mathrm{H}} \sin \beta\right] \tan \varphi_{\mathrm{a}}+\mathrm{R}_{\mathrm{A}} / \mathrm{W}}{\left(1-\sigma_{\mathrm{v}}\right) \sin \beta-\sigma_{\mathrm{H}} \cos \beta}
$$

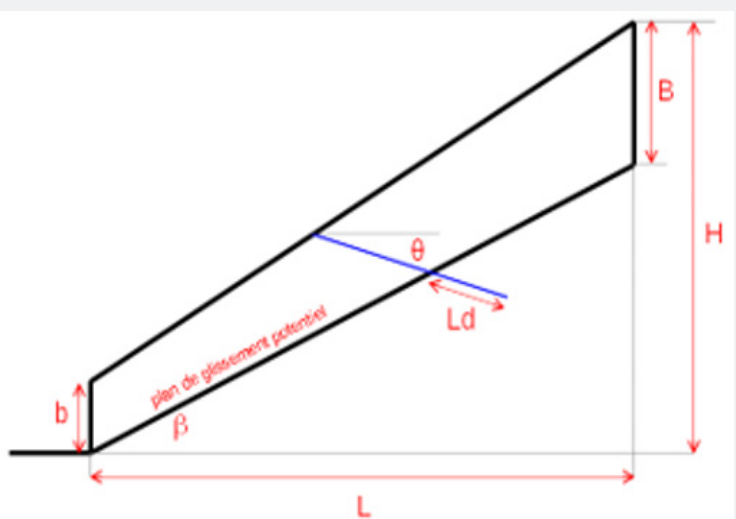

Figure 15: Plan of the rock fall slope with the potential sliding plan (F1).

With:

L: Horizontal length of the sliding plan.

$\mathrm{H}$ : Height comforted slope.

$\beta$ : Inclination of the sliding plan Slope compared with the horizontal.

$\theta$ : Inclination of the anchoring compared with horizontal.

Ld: Sealing length.

Y: Natural or saturated weight volume.

qs: Unitary lateral friction.

$\varphi$ : Apparent angle of friction along the sliding plan.

W: Compartment weight to be consolidated.

RA: Contribution of anchoring (parallel to the sliding and of opposed sense) Table 2.

Table 2: Geometrical and mechanical characteristics retained for the sizing.

\begin{tabular}{|c|c|c|c|}
\hline Geometrical Data & Values & Data on to the Rocky Material & Values \\
\hline $\mathrm{b}=$ & $6.5 \mathrm{~m}$ & $\gamma=$ & $26 \mathrm{kN} / \mathrm{m} 3$ \\
\hline $\mathrm{B}=$ & $17.8 \mathrm{~m}$ & $\mathrm{qs}=$ & $650 \mathrm{kPa}$ \\
\hline $\mathrm{L}=$ & $15.0 \mathrm{~m}$ & $45^{\circ}$ \\
\hline $\mathrm{H}=$ & $59.0 \mathrm{~m}$ & & \\
\hline$\beta=$ & $70.0^{\circ}$ & & \\
\hline
\end{tabular}

\section{System of a Realized Reinforcement}

The realized strengthening System is consisted of steel bars with an equal diameter of $20 \mathrm{~mm}$ and elastic limit equal to $950 \mathrm{MPa}$, setting place in drillings of an equal diameter of $90 \mathrm{~mm}$ and tilted by $20^{\circ}$ with regard to the horizontal, with an average square stitch of $0,71 \mathrm{~m} \times 0,71 \mathrm{~m}$ (Figure 16). The length of sealed bars at the back of potential sliding plan (F1) (Figure 8) is fixed to $6 \mathrm{~m}$ on the other hand the total length of bars is determined according to their position in the slope. It varies between $8 \mathrm{~m}$ and $11,5 \mathrm{~m}$ (Figure 17). 


\section{Civil Engineering Research Journal}

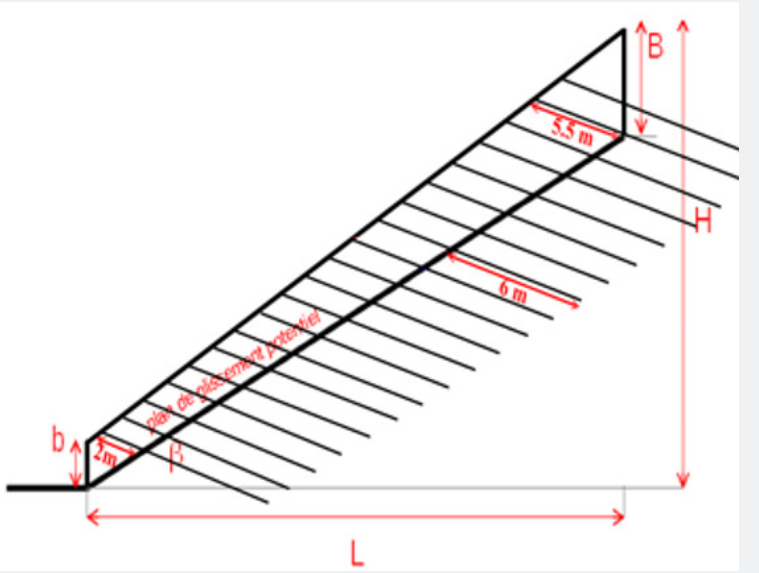

Figure 16: Passive realized nailing.

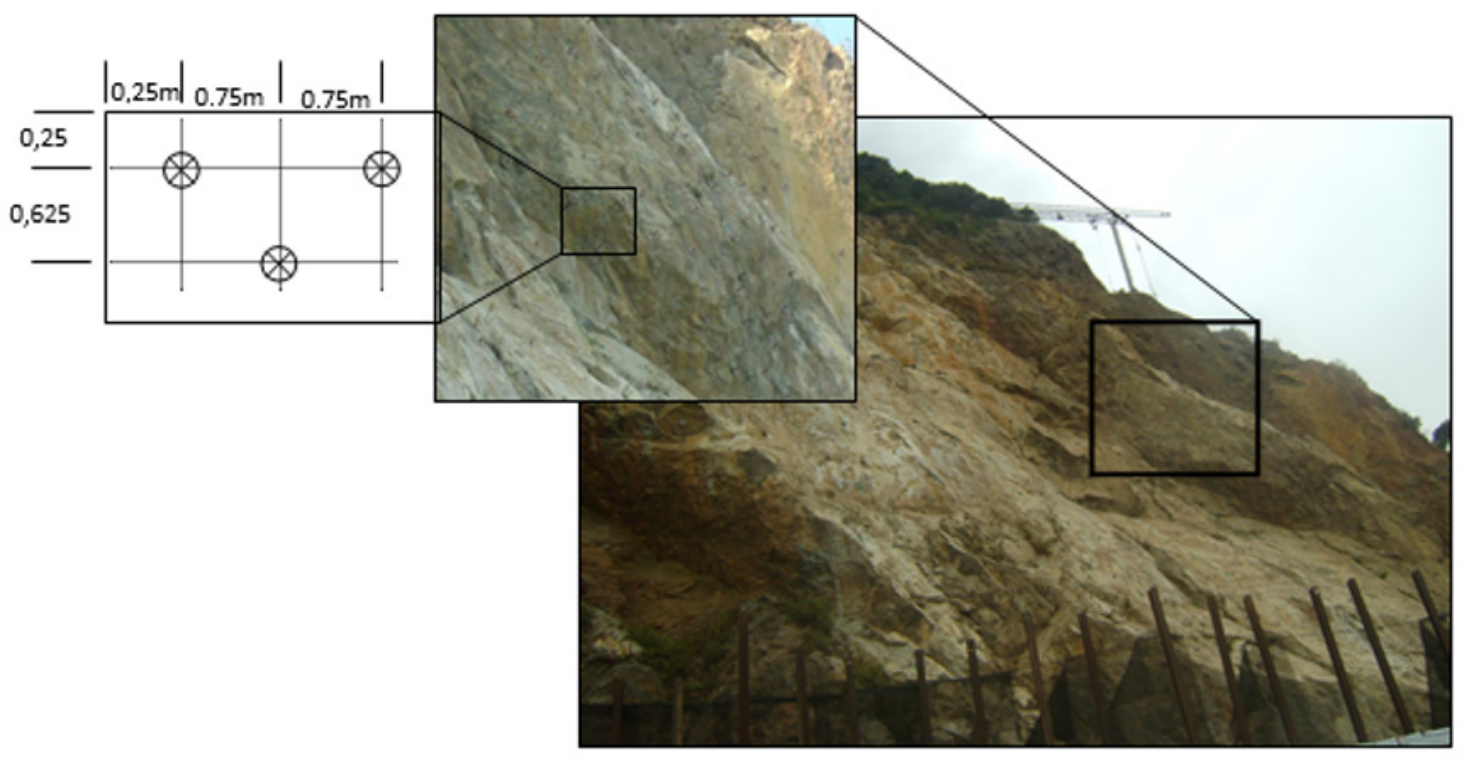

Figure 17: Reinforcement by Nailing realized in the slope cleared by the rock fall of May, 2005.

The reinforcement, thus validated by the contracting strengthening is Fs=1, 3 .

authority, is widely oversized with safety factors equal in:

a) 3,4 without earthquake,

b) And at 5, 1 under reference earthquake.

The reinforcement rests on small diameter bars (without consideration the reduction bound to the corrosion), in steel very stiff and according to a small dimensions square stitch, induced an intense cutting of the rock massif. The remainder of article presents a possible optimization of the nailing.

\section{Proposal Optimization of the Sizing}

The dimensioned situation is the one without earthquake with the same data used previously. The safety factor aimed after
The bars implementation an equal diameter of $50 \mathrm{~mm}$ (with a reduction of $8 \mathrm{~mm}$ in diameter among 100 years due to the corrosion) and of elastic limit equal to $500 \mathrm{MPa}$, with an average square stitch of $2,04 \mathrm{~m} \times 2,04 \mathrm{~m}$, allows to result in equal safety coefficient in:

a. 1,3 without earthquake,

b. And in 1,6 under reference earthquake.

The length of sealed bars in the back of the potential plan sliding (F1) (Figure 8) will be at least $3,5 \mathrm{~m}$ at the back of the unstable potentially plan (F1). The bars total length is determined according to their position in the slope. It is between $5 \mathrm{~m}$ and $9 \mathrm{~m}$ (Figure 18). 


\section{Civil Engineering Research Journal}

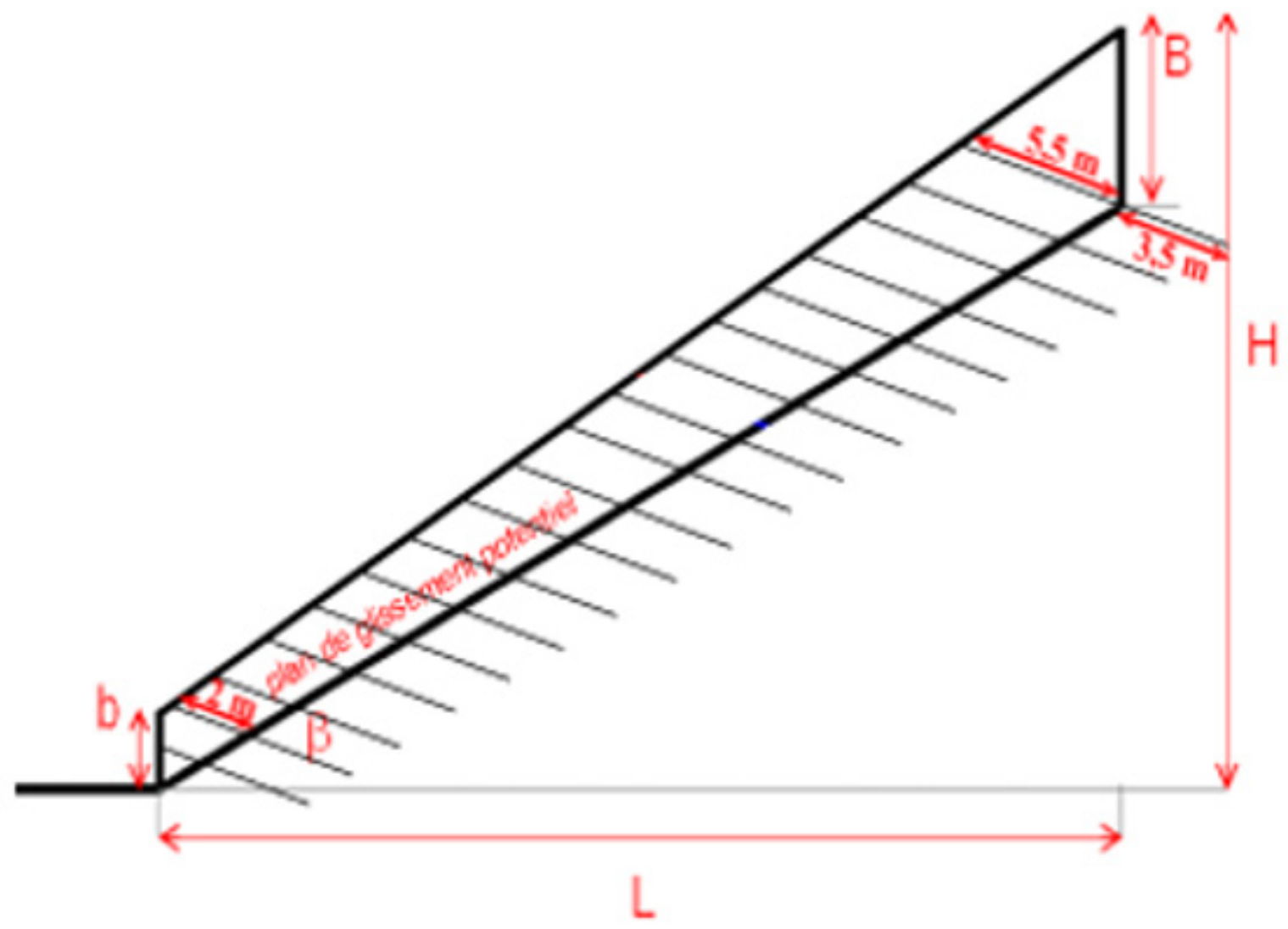

Figure 18: Optimized passive nailing.

\section{Results and Discussion}

The rock fall of Cap Aokas (May 2005) on the west side of the current RN9 tunnel is occurred following a fracture oriented $\mathrm{N} 087^{\circ}$ to $\mathrm{N} 090^{\circ}$. The released plan by the rock fall shows continuity over several $\mathrm{m} 2$, a regularity of its surface that is smooth enough and may distorted. It presents a precarious stability. The obtained safety coefficients in both situations (excluding earthquake and under reference earthquake) show that the realized retaining system is oversized (steel bars with a diameter of $20 \mathrm{~mm}$, yield stress equal to $950 \mathrm{MPa}$, drilling with a diameter of $90 \mathrm{~mm}$ and inclined at $20^{\circ}$ relative to the horizontal, average square mesh of $0.71 \mathrm{~m} \times 0.71 \mathrm{~m}$ and a length of the bars sealed behind the potential sliding plane set at $6 \mathrm{~m}$ ), we wonder if its size is not excessive. However, the mesh of small dimensions, can induce intense cutting of the rock mass under the reference earthquake. The optimization of the design shows that the proposed retaining system ensures the stability of the slope in both situations excluding earthquake and under reference earthquake

\section{Conclusion}

In the study term of the reinforcement project of the rock fall scar of May 2005, the various aspects (geology, fracturing of the massif, the seismicity and geotechnical) allowed us to end in a detailed analysis of the slope stability. Small diameter bars (without consideration of a possible reduction bound to the corrosion in marine environment), very stiff steel and a small square stitch (induce an intense cutting of rock massif). The reinforced slope will have to be considered as a sensitive structure and be the specific surveillance object by the contracting authority (Periodic inspections, follow-up by infrared geodesic measures). This new rock falls put in evidence the necessity of detailed diagnosis towards the rocky risk on the threatened whole section of the NR9, on a linear about $1,2 \mathrm{~km}$. A particular attention will have to be given to the strengthening sizing by passive nailing of the unstable rocky slope in the Melbou ledge after the completion works of the NR43 extension (Figure 19), situated in approximately $15 \mathrm{~km}$ east of Aokas area. 


\section{Civil Engineering Research Journal}

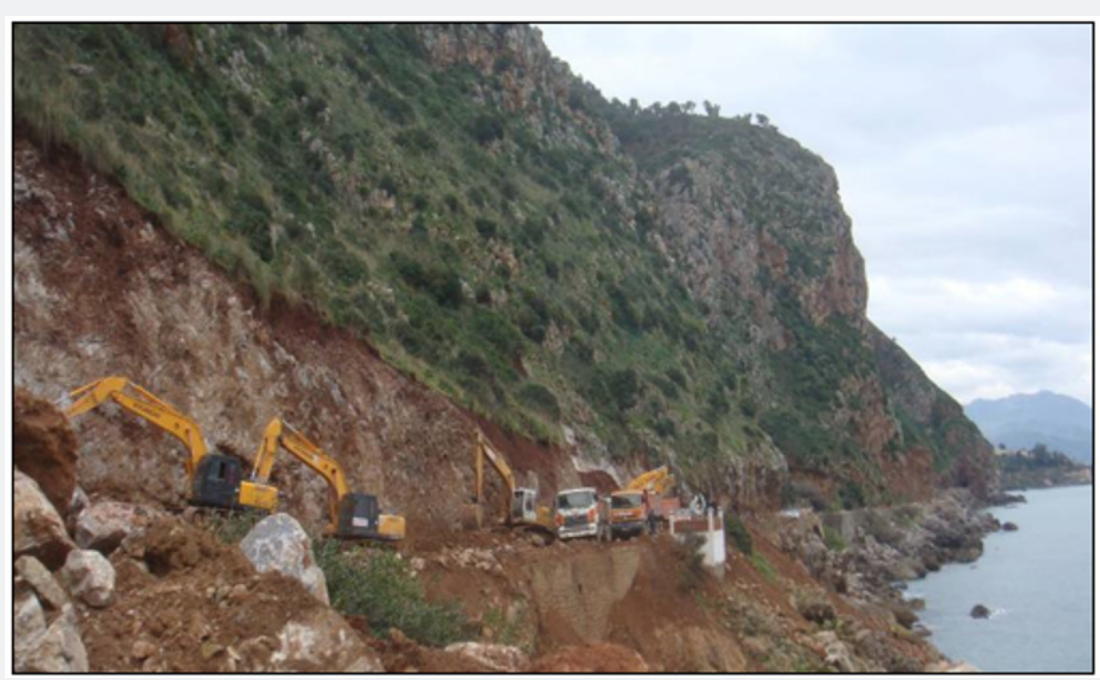

Figure 19: Widening works of the RN43 (calcareous cliff of the Melbou ledge).

\section{References}

1. Leikine M (1971) Etude géologique des Babors occidentaux (Algérie). Thèse de doctorat. Université de Paris, Paris, France.

2. Bougdal R (2009) Doublement du tunnel de Cap Aokas, synthèse des données géologiques et géotechniques.

3. Meghraoui M, Maouche S, Chemaa B, Cakir Z, Aoudia A, et al. (2004) Coastal uplift and thrust faulting associated with the $\mathrm{M}=6.8$ Zemmouri (Algeria) earthquake of 21 May 2003. Geophysical Research Letters 31(19): 2004

4. Kirèche 0 (1993) Evolution géodynamique de la marge tellienne des Maghrébides d'après l'étude du domaine parautochtone schistosé. Thèse doctorat sciences, Université d'Alger (USTHB), Alger, Algeria.

5. Hallal N, Bougdal R, Bensafia W (2013) Dédoublement du tunnel d'Aokas (BEJAIA): géologie et caractérisation géotechnique du massif traversé. Stabilité de l'ouvrage. Bull Eng Geol Environ 3(4): 2013.
6. Bensafia W, Hallal N (2011) Dédoublement du tunnel d'Aokas (BEJAIA) géologie et caractérisation géotechnique du massif traversé. Mémoire Master, USTHB, Algeria.

7. Machane D, Guillier B, Chatelain J, Bouillin B, Haddoum H, et al. (2009) Le séisme de Laâlam (Kabylie, Algérie) du 20 mars 2006: prospections géologiques et géophysiques (bruit vibration ambiant) et corrélations avec les dommages. Bull du service géologique national 22(3): 357373.

8. Beldjoudi H, Guemache MA, Kherroubi A, Semmane F, Yelles-chaouche AK, et al. (2009) The Laâlam (Béjaïa, North-East Algeria) Moderate Earthquake $(M w=5.2)$ on March 20, 2006. Pure appl geophys 166: 623-640.

9. Bouhadad Y, Nour A, Laouami N, Belhai D (2003) The Beni-OurtilaneTachaouaft fault and Seismotectonic aspects of the Babors region (NE of Algeria) Journal of Seismology 7: 79-88.

\section{Your next submission with Juniper Publishers will reach you the below assets}

- Quality Editorial service

- Swift Peer Review

- Reprints availability

- E-prints Service

- Manuscript Podcast for convenient understanding

- Global attainment for your research

- Manuscript accessibility in different formats

( Pdf, E-pub, Full Text, Audio)

- Unceasing customer service

Track the below URL for one-step submission https://juniperpublishers.com/online-submission.php 